\title{
PENGARUH PEMBIAYAAN PERUSAHAAN TERHADAP NILAI PERUSAHAAN MANUFAKTUR
}

\author{
Herni Kurniawati ${ }^{1 *}$, Fanny Andriani Setiawan ${ }^{2}$ \\ ${ }^{1}$ Jurusan Akuntansi, Universitas Tarumanagara Jakarta \\ Email: hernik@fe.untar.ac.id \\ 2 Jurusan Akuntansi, Universitas Tarumanagara Jakarta \\ Email: fannys@fe,untar.ac.id \\ *penulis korespondensi
}

Masuk : 12-04-2021, revisi:24-06-2021, diterima untuk diterbitkan : 25-06-2021

\begin{abstract}
ABSTRAK
Perusahaan yang didirikan bertujuan untuk memaksimalkan kekayaan investor dengan cara menambah nilai perusahaan, berdampak pada peningkatan harga saham, dan peningkatan jumlah deviden. Selain itu, nilai perusahaan yang tinggi juga memberikan kepercayaan pasar terhadap kinerja perusahaan saat ini dan yang akan datang, yang mempengaruhi investor untuk berinvestasi, dan kreditor memberikan pinjaman kepada perusahaan. Mewujudkan peningkatan nilai perusahaan dilakukan oleh beberapa tindakan manajemen yaitu keputusan pembiayaan yang tepat, kebijakan dividen, ukuran perusahaan, leverage, profitabilitas, dan lain-lain. Penelitian ini bertujuan untuk membuktikan secara empiris bagaimana keputusan pembiayaan perusahaan dengan utang / leverage dan utang. kematangan mempengaruhi nilai perusahaan manufaktur. Metode penelitan menggunakan regresi data panel sebanyak 248 data observasi perusahaan publik terdaftar di BEI. Sampelnya adalah perusahaan manufaktur, dengan laporan keuangan sebagai data sekunder laporan tahunan periode 2016-2019 sebagai data penelitian. Hasilnya adalah (1) Pembiayaan perusahaan menggunakan leverage tidak dapat meningkatkan nilai perusahaan; (2) Pembiayaan perusahaan yang menggunakan debt maturity tidak dapat meningkatkan nilai perusahaan manufaktur.
\end{abstract}

Kata Kunci: Pembiayaan perusahaan, nilai perusahaan

\begin{abstract}
The company that was founded aims to maximize investor wealth by adding value to the company, having an impact on increasing share prices and increasing the amount of dividends. In addition, high company value also provides market confidence in the company's current and future performance, which influences investors to invest, and creditors provide loans to the company. Realizing an increase in company value is carried out by several management actions, namely the right financing decision, dividend policy, company size, leverage, profitability, and others. This study aims to prove empirically how the corporate financing decisions with debt / leverage and debt. maturity affects the value of the manufacturing company. The research method uses panel data regression as much as 235 observation data of public companies listed on the IDX. The sample is manufacturing companies, with financial reports as secondary data for the 2016-2019 period as research data. The results are (1) corporate financing using leverage cannot increase firm value; (2) Financing companies that use debt maturity cannot increase the value of manufacturing companies.
\end{abstract}

Keywords: Financing structure, firm value

\section{PENDAHULUAN}

\section{Latar Belakang}

Perusahaan yang didirikan memiliki dua tujuan yaitu pertama memaksimalkan kekayaan pemegang saham, dan kedua perusahaan dapat beroperasi secara going concern (beroperasi untuk waktu yang lama dan tidak gulung tikar). Salah satu cara mewujudkan tujuan perusahaan yang memaksimalkan kekayaan investor yaitu dengan meningkatkan nilai perusahaan, yang berdampak kepada kenaikan harga saham perusahaan tersebut. Kenaikan harga saham pada akhirnya memberikan kenaikan jumlah return saham yang diperoleh pemegang saham (E. F. \& Brigham \& Gapenski, 2006). Selain itu nilai perusahaan yang tinggi dapat memberikan dampak dipercayanya kinerja perusahaan saat ini dan masa depan oleh pasar (Sutama \& Lisa, 2018), 
yang memberikan pengaruh yang positif terhadap investor dan kreditur. Pengaruh positif yang disampaikan merupakan sinyal positif untuk investor untuk menanamkan modalnya di perusahaan. Sedangkan pengaruh positif untuk kreditur adalah nilai perusahaan yang tinggi menggambarkan bawah perusahaan tersebut memiliki kemampuan melunasi kewajibannya, hal tersebut memberikan rasa aman bagi pihak kreditur untuk menyerahkan pinjaman uang bagi perusahaan tersebut. Sehingga dapat disimpulkan bahwa meningkatkan nilai perusahaan adalah hal yang perlu dilakukan perusahaan selama beroperasi, dan untuk mewujudkannya perusahaan dapat melakukan beberapa aksi yaitu melakukan keputusan pembiayaan yang tepat, firm size, capital structure yang tepat, keputusan menanamkan modal, pertumbuhan perusahaan, leverage, dan profitabilitas (Chaleeda et al., 2019).

Penelitian ini memiliki fenomena yang berkaitan dengan keputusan pembiayaan, dimana merupakan salah satu keahlian pengambilan keputusan keuangan terumit karena memiliki kaitan dengan faktor keputusan keuangan yang lain (Nimalathasan, Balasundaram \& Brabete, 2010). Masalah dari penelitian ini terletak pada kurangnya kejelasan mengenai pengaruh struktur pembiayaan (modal) terhadap nilai perusahaan, dimana manajer perlu memilih struktur pembiayaan yang sesuai bagi perusahaan yang berkontribusi untuk memaksimalkan nilainya, dan dengan demikian memaksimalkan kekayaan perusahaan. pemilik perusahaan.

\section{Rumusan Masalah}

Berdasarkan hasil beberapa penelitian yang mengkaitkan struktur pembiayaan dengan nilai perusahaan seringkali menunjukkan hasil tidak konsisten sampai dengan saat ini, yang dibuktikan oleh penelitian (Chaleeda et al., 2019) bahwa struktur pembiayaan perusahan yang menggunakan utang memberikan dampak positif signifikan atas nilai perusahaan. Alasannya karena tingginya nilai leverage dalam laporan posisi keuangan dapat memberikan keuntungan pajak (tax benefit) perusahaan. Hasil riset Chaleeda et al. tersebut mendukung hasil riset (Cheng \& Tzeng, 2011) yang membuktikan tingginya leverage memberikan dampak positif atas nilai perusahaan karena leverage yang lebih tinggi mampu menurunkan biaya agensi dari arus kas bebas melalui komitmen pembayaran bunga dan menghindari investasi berlebih. Sedangkan menurut hasil penelitian (Rashid et al., 2013); (Asif \& Aziz, 2016) penggunaan leverage (utang) sebagai pembiayaan perusahaan merupakan dana eksternal yang menyebabkan penggunaan utang yang lebih tinggi akan meningkatkan pengawasan eksternal.

Hasil penelitian bertolak belakang yang dibuktikan oleh (Vo \& Ellis, 2017) bahwa perusahaan di Vietnam yang nilai leverage rendah cenderung menciptakan nilai bagi pemegang saham. Mereka menyelidiki hubungan antara struktur modal dan nilai pemegang saham pada perusahaan Vietnam membuktikan bahwa manfaat pembiayaan utang lebih rendah dibandingkan biaya utang yang dikeluarkan sehingga memiliki pengaruh buruk terhadap nilai perusahaan Vietnam. Hasil riset mereka serupa hasil temuan (Daud et al., 2016) dan (Tan \& Hamid, 2016) yang setuju bahwa total utang terhadap total aset dan kinerja perusahaan mempunyai korelasi signifikan. Penelitian (Fajaria \& Isnalita, 2018) juga membuktikan hasil yang sama bahwa tingginya penggunaan utang sebagai pembiayaan perusahaan dapat menurunkan nilai perusahaan karena. Alasannya karena perusahaan yang utangnya tinggi, biasanya tingkat resiko gagal bayar juga tinggi, dan hal tersebut berdampak atas minat investor yang berencana berinvestasi di perusahaan tersebut. Selain hasil penelitian pembiayaan perusahaan dengan utang (leverage) yang dapat menaikkan dan menurunkan nilai perusahaan, terdapat juga hasil penelitian yang membuktikan leverage tidak menaikkan dan menurunkan nilai perusahaan seperti hasil penelitian (Sisca, 2018) karena investor memiliki kecendrungan mencermati cara manajemen menggunakan utang perusahaan dalam mengembangkan perusahaan secara efektif dan efisien serta berdampak pada 
memberikan nilai tambah untuk perusahaan tersebut. Hasil riset tersebut mendukung hasil riset (Novari \& Lestari, 2016) yang membuktikan bahwa tingginya nilai leverage tidak berdampak atas nilai perusahaan, Menurut mereka bahwa rata-rata perusahaan menggunakan laba ditahan dan saham, modal sendiri (internal financing), untuk mendanai asetnya. Oleh karena itu perusahaan-perusahaan tersebut menurunkan jumlah utang dalam mendanai operasional perusahaan. Berdasarkan dari beberapa hasil penelitian pembiayaan perusahaan yang memakai utang/ leverage terhadap nilai perusahaan memberikan hasil yang tidak konsisten, yaitu berdampak positif, negatif, dan tidak berdampak, yang memotivasi dilakukan penelitian ini dengan sampel perusahaan manufaktur. Sehingga rumusan masalah pertama penelitian adalah: Apakah leverage berpengaruh positif terhadap nilai perusahaan?

Kebaruan penelitian ini menambahkan variabel debt maturity yang merupakan aspek lain dari pembiayaan perusahaan yang terbukti mempengaruhi nilai perusahaan. Debt maturity memiliki jatuh tempo yang lebih pendek sehingga meningkatkan nilai perusahaan yang disebabkan utang jatuh tempo yang lebih pendek menguntungkan perusahaan karena mengurangi masalah kurangnya investasi dan penggantian aset (Myers, 1977). Selain itu,(Berlin, 2006)) menggarisbawahi bahwa ketika perusahaan memiliki terlalu banyak utang jangka panjang, manajer mungkin melupakan investasi yang menguntungkan. Penelitian (Jiraporn \& Liu, 2008) membuktikan bahwa perusahaan yang mengadopsi jumlah utang jangka panjang yang lebih tinggi dari utang jangka pendek mengalami peningkatan nilai perusahaan, konsisten dengan prediksi teori keagenan dan hipotesis arus kas bebas. Situasi ini terutama berlaku untuk perusahaan di industri dengan konflik keagenan yang lebih rendah (seperti utilitas yang diatur). Sehingga rumusan masalah kedua penelitian adalah: Apakah debt maturity berpengaruh positif terhadap nilai perusahaan?

\section{TINJAUAN PUSTAKA}

Signalling Theory. Arti dari teori sinyal adalah ketika perusahaan memberikan sinyal atas laporan keuangan kepada investor dengan tujuan untuk meningkatkan nilai investor (Fajaria \& Isnalita, 2018). Sinyal tersebut berwujud informasi yang berkaitan dengan usaha manajemen untuk mewujudkan apa yang dibutuhkan investor, atau informasi yang bisa menyatakan bahwa perusahaannya memiliki kinerja lebih unggul dibandingkan perusahaan lainnya (Fajaria \& Isnalita, 2018). Sinyal tersebut dibagikan dengan tujuan untuk menurunkan asimetri informasi, karena biasanya pihak internal perusahaan sangat memahami kondisi perusahaan dibandingkan pihak eksternal perusahaan (Fajaria \& Isnalita, 2018). Berdasarkan teori sinyal, penggunaan utang sebagai pembiayaan perusahaan merupakan informasi baik bagi investor karena dengan pembiayaan perusahaan menggunakan utang dapat memberikan debt tax shield bagi perusahaan. Efek dari debt tax shield bagi perusahaan adalah menurunkan kuantitas pajak yang wajib dibayar sehingga meningkatkan kenaikan laba yang pada akhirnya memberikan dividen kepada investor lebih tinggi. Hal tersebut yang menjadikan perusahaan tersebut memiliki nilai perusahaan yang tinggi (Wang, 2015); (Twairesh, 2014) (Chaleeda et al., 2019).

Agency theory yang berkaitan dengan utang adalah perselisihan yang terjadi antara pemegang saham dan kreditur menurut (Ehikioya, 2009) pada hasil risetnya. Akan tetapi, pemakaian utang yang terlalu banyak dapat memunculkan persoalan lain bagi agency theory. Utang dapat menimbulkan perselisihan antara investor dan kreditur, salah satunya adalah apabila ada beberapa syarat yang spesifik tertuang dalam perjanjian utang (kreditur) yang bertolak belakang dari yang diharapkan seorang investor (Ehikioya, 2009). Agency theory yang dikaitkan oleh debt maturity memberikan pengaruh baik bagi perusahaan, karena debt maturity bisa menjadi salah satu cara mengutangi biaya agensi utang dengan menyelesaikan masalah substitusi aset dan 
underinvestment (Myers, 1977). Debt maturity juga merupakan salah satu bentuk pembiayaan eksternal dan membutuhkan pembaruan yang sering sehinga secara tidak langsung akan meningkatkan pengawasan eksternal dan dengan demikian akan memberikan peningkatan nilai perusahaan.

Trade-off Theory. Pembiayaan perusahaan yang ada di perusahaan saat ini terbagi menjadi dua yaitu menggunakan utang dan ekuitas. Menurut teori Trade-off bahwa perusahaan yang menggunakan utang sebagai pembiayannya memberikan keuntungan dengan memperoleh debt tax shield dari pemerintah (E. F. dan J. F. H. Brigham, 2014). Teori Trade-off juga memberikan penjelasan bahwa apabila struktur modal posisinya ada dibawah titik optimal, maka utang yang bertambah berdampak menaikkan nilai perusahaan. Sedangkan apabila struktur modal posisinya ada diatas titik optimal, maka utang yang bertambah berdampak menurunkan nilai perusahaan (Brealey, R.A. \& Myers, 2003).

Nilai Perusahaan. Tobins ' $Q$ adalah salah satu alat untuk menganalisis keuangan dengan tujuan menilai kinerja perusahaan khususnya keuangan. Dalam beberapa riset bahwa rasio Tobin's $Q$ dimanfaatkan menghitung berapa besar nilai suatu perusahaan, lewat digunakan untuk mengetahui nilai perusahaan melalui kemampuan harga saham yang berkembang dan kemampuan seorang manajer bagaimana dalam mengatur asset perusahaan, pertumbuhan perusahaan dan mengatur investasi.). Tobins' $Q$ merupakan proksi mengukur nilai perusahaan paling akurat dengan alasan pertama rumus dari Tobin's $Q$ terdiri dari nilai pasar saham biasa dan kewajiban keuangan, maka Tobins ' $Q$ lebih unggul (Octaviana, Lisa Tyas, Hasnawati, Sri, \& Hendrawaty, 2019). Keunggulan lainnya dari Tobins' $Q$ berdasarkan rumusnya terdapat unsur kewajiban sehingga bisa dipastikan rasio Tobins' $Q$ adalah paling rasional. Penelitian ini menggunakan rumus Tobins' $Q$ oleh (Octaviana, Lisa Tyas, Hasnawati, Sri, \& Hendrawaty, 2019):

$$
\mathrm{Q}=(\mathrm{EMV}+\mathrm{D}) /(\mathrm{EBV}+\mathrm{D})
$$

dimana:

$\mathrm{EMV}=$ Equity market value

$\mathrm{EBV}=$ Book value total asset

$\mathrm{D} \quad=$ Book value total liabilities

Rasio Tobin's $Q$ memberikan nilai maksimum 1, dimana apabila nilai Tobins' $Q$ kurang dari 1 memiliki arti bahwa saham mengalami undervalued yaitu menggambarkan adanya investasi yang bertumbuh di perusahaan tersebut. Lain hal nya, jika nilai rasio Tobins' $Q$ adalah 1 memberikan arti bahwa saham mengalami overvalued. Artinya bahwa investasi tidak mengalami pertumbuhan di perusahaan tersebut.

Pembiayaan Perusahaan. Keputusan pendanaan perusahaan yang benar yang ditentukan oleh manajer keuangan harusnya dapat menambah nilai perusahaan, dan berdampak kepada peningkatan kesejahteraan pemilik perusahaan. Berdasrkan kenyataan bahwa banyak faktor yang mempengaruhi bertambahnya nilai perusahaan antara lain capital structure, firm size, investment decision, company growth, funding decision, dividend policy, dan debt policy. Berdasarkan hasil beberapa penelitian telah membuktikan bahwa beberapa faktor tersebut memberikan hasil yang tidak selalu sama antara hasil riset satu dengan hasil riset lainnya (Novari \& Lestari, 2016). Sehingga menurut hasil riset (Novari \& Lestari, 2016) dari semua faktor yang dijabarkan di atas bahwa faktor firm size, leverage (capital structure), dan profitabilitas yang dapat menambah nilai perusahaan. 


\section{Capital Structure}

Capital structure memilik arti sebagai sumber pembiayaan perusahaan jangka panjang (leverage, equity, bauran leverage dan equity) yang digunakan dimana dikelola dengan tujuan memaksimalkan harga saham dan juga smenaikkan nilai perusahaan. (E. F. dan J. F. H. Brigham, 2014). Teori capital structure yang diperkenalkan Modigliani-Miller dianggap sebagai capital structure modern pertama dan kontroversial di tahun 1958, karena penggunaan leverage atau equity akan memberikan dampak yang sama atas kemakmuran perusahaan dengan asumsi tidak ada pajak perusahaan. Oleh karena kontroversi tersebut, teori Modigliani-Miller menimbulkan lahirnya teori struktur modal baru yang dikenal dengan teori trade off dan teori pecking order, dengan mempertimbangkan unsur pajak dalam teori tersebut.

Leverage. Perusahaan menggunakannya untuk menilai bagaimana perusahaan memilki kapabilitas melunasi kewajiban jangka Panjang dan kewajiban jangka Pendek (Hery, 2016). Leverage terbagi menjadi tiga jenis didalam manajemen perusahaan yaitu financial leverage, operating leverage, dan total leverage. Adapun jenis-jenis rasio leverage yang umumnya dipergunakan di beberapa riset mencakup:

Debt to Assets Ratio (DAR). Rasio dipakai menilai besarnya assets yang dimiliki perusahaan di biayai oleh utang, atau memiliki arti berapa besarnya utang yang dimiliki perusahaan berdampak terhadap manajemen assets (Kasmir, 2014). Debt to Equity Ratio (DER). Rasio dipakai menilai utang dengan modal yang dimiliki perusahaan. Selain itu rasio tersebut dapat digunakan untuk memahami berapa dana yang diberikan oleh kreditur dengan pemilik perusahaan (Kasmir, 2014). Long Term Debt to Equity Ratio. Adalah rasio yang menilai utang jangka Panjang atas ekuitas perusahaan. Time Interest Earned (TIE). Rasio ini menilai berapa besarnya operating income mendapati penurunan sebelum perusahaan tidak mampu membayar biaya bunga tahunannya (Kasmir, 2014). Fixed Charge Coverage. Memiliki kegunaan yang sama dengan rasio TIE dengan memiliki perbedaan sedikit yaitu dilakukan jika perusahaan mendapatkan utang jangka Panjang atau mengontrak asset berlandaskan kontrak sewa (Kasmir, 2014). Kesimpulannya riset ini memakai rasio leverage Debt to Assets Ratio (Total Debt/ Total Assets).

Debt Maturity. Utang dalam laporan posisi keuangan terdiri dari utang jangka Panjang dan utang jangka pendek. Definisi utang jangka pendek adalah utang yang sifatnya segera dilunasi maksimal satu tahun setelah tanggal pelaporan dilakukan. Definisi dari utang jangka Panjang adalah utang yang jangka waktu pelunasannya lebih dari satu periode/ tahun setelah dilakukannya tanggal pelaporan di laporan posisi keuangan (Suaidah, Riski \& Sebrina, 2020). (Myers, 1977) menyarankan perusahaan untuk menggunakan utang jangka pendek dengan alasan mengurangi masalah kurangnya investasi dan subsitusi aset sehingga dapat meningkatkan nilai perusahaan (Chaleeda et al., 2019). Hal ini disebabkan karena utang jangka pendek akan di likuidasi dalam periode yang cepat sehingga semua keuntungan dipastikan menjadi hak perusahaan tersebut. Selain itu, utang jangka pendek yang dipakai dapat meminimalisir masalah agensi antara pemegang saham dengan kreditur sehingga masalah kurangnya/ kelebihan investasi (Myers, 1977); (Suaidah, Riski \& Sebrina, 2020). Selain itu (Berlin, 2006) menggarisbawahi bahwa ketika perusahaan memiliki terlalu banyak utang jangka panjang, manajer mungkin melupakan investasi yang menguntungkan dan dampaknya menurunkan nilai perusahaan.

Secara empiris, cukup banyak proksi yang telah digunakan untuk debt-maturity. Seperti (Ozkan, 2000) telah menggunakan proporsi kewajiban yang jatuh tempo 5 tahun atau 1 tahun terhadap total kewajiban. (Barclay \& Smith, 1995) menggunakan proporsi utang yang jatuh tempo lebih dari tiga tahun atas jumlah utang. Tetapi sumber data tidaklah sama mengenai jatuh tempo utang 
di setiap perusahaan. Oleh karena itu menyetujui kendala tersebut, penelitian ini menilai jatuh tempo utang sebagai berikut: (Jamal, Surayya, Naveed \& Malik, 2020); (Fan et al., 2012); (Orman \& Köksal, 2017) Debt Maturity = utang jangka panjang / utang total.

\section{Hipotesis Penelitian}

Penelitian ini akan melihat keputusan pembiayaan perusahaan dari dua dimensi; leverage dan debt maturity (utang jatuh tempo). Perusahaan Malaysia banyak menggunakan leverage sebagai pembiayaan perusahaan karena dapat memberikan manfaat pajak atas utang (debt tax shield), sehingga meningkatkan nilai perusahaan (Mohd Tahir \& Razali, 2011)). Selain itu arus kas bebas dibuktikan menaikkan dampak positif leverage atas nilai perusahaan, dengan alasan adanya komitmen membayar bunga dan juga untuk mencegah adanya investasi yang berlebihan, dimana leverage efektif untuk mengurangi masalah keagenan arus kas bebas (Cheng \& Tzeng, 2011). Pengaruh positif leverage terhadap nilai perusahaan kemudian akan tercermin pada kenaikan harga saham. (Mohd Tahir \& Razali, 2011) membuktikan adanya hubungan positif yang benar dalam penelitiannya terhadap perusahaan terbuka Malaysia. Alasannya karena melalui leverage, perusahaan dapat memperoleh peluang investasi dalam bisnis mereka tanpa meningkatkan ekuitasnya. Karenanya, ketika investasi menguntungkan, nilai pemegang saham kemudian akan meningkat. Hubungan nilai utang yang positif dimungkinkan untuk perusahaan Malaysia karena mereka tidak sangat bergantung pada utang, mengutip utang rata-rata hanya 23\% (Rashid et al., 2013). Selain itu, (Rashid et al., 2013) menambahkan bahwa utang adalah dana eksternal, sehingga penggunaan utang yang lebih tinggi akan meningkatkan pemantauan eksternal, manajer menjadi sasaran pemantauan eksternal oleh lembaga pemeringkat, investor, dan penjamin emisi pada saat penerbitan. Hal tersebut menciptakan manfaat sampingan dari leverage yang mengurangi biaya agensi atas kebijaksanaan manajerial, sehingga memberikan kontribusi positif terhadap nilai perusahaan. Hasil tersebut di dukung (Hermuningsih, 2013) yang melakukan penelitiannya di Indonesia, penambahan leverage memberikan sinyal positif bagi investor dan juga meningkatkan nilai perusahaan. Penelitian (Hermuningsih, 2013) juga setuju bahwa kewajiban dapat membantu perusahaan untuk mengontrol menggunakan arus kas yang tersedia secara bebas dan berlebihan di dalam perusahaan oleh manajemen. Oleh karena itu, penelitian ini membuat hipotesis bahwa leverage memiliki pengaruh positif dan signifikan atas nilai perusahaan. Sehingga perumusan hipotesisnya adalah:

H1: Leverage berpengaruh positif terhadap nilai perusahaan.

Penelitian ini menambahkan debt maturity (utang jatuh tempo) sebagai komponen pembiayaan perusahaan yang lain. Alasannya karena penelitian ini berpendapat bahwa debt maturity memberikan dampak positif atas nilai perusahaan. Faktanya, utang yang jatuh temponya lebih pendek dapat mengurangi biaya agensi utang dengan menyelesaikan masalah substitusi aset dan underinvestment (Myers, 1977). Debt maturity juga merupakan salah satu bentuk pembiayaan eksternal dan membutuhkan pembaruan yang sering. Secara tidak langsung akan meningkatkan pengawasan eksternal dan dengan demikian akan memberikan kontribusi positif terhadap nilai perusahaan. (Jiraporn \& Liu, 2008) terbukti bahwa perusahaan yang lebih banyak menggunakan debt maturity, maka memanfaatkan lebih banyak utang jangka pendek mempunyai nilai perusahaan yang lebih tinggi, dan hubungannya lebih kuat untuk perusahaan dengan masalah keagenan yang lebih tinggi. Sehingga, riset ini mengusulkan adanya pengaruh negatif utang jatuh tempo terhadap nilai perusahaan. Sehingga perumusan hipotesisnya adalah:

H2: Debt maturity berpengaruh negatif terhadap nilai perusahaan 


\section{METODE PENELITIAN}

Populasi dan Sampel. Populasi riset terdiri dari seluruh perusahaan manufaktur yang terdaftar di Bursa Efek Indonesia (BEI). Sedangkan sampel riset adalah perusahaan manufaktur tahun 2016-2019, dengan memanfaatkan teknik purposive sampling. Tujuannya agar mendapatkan sampel selaras dengan kualifikasi yang telah ditetapkan. Adapun kualifikasinya terdiri dari: (1)Terdaftar di BEI secara terus menerus dalam kurun periode 2016-2019; (2)Tidak mengalami kerugian dalam kurun periode 2016-2019; (3)Laporan keuangannya menggunakan mata uang rupiah (simbol: IDR); (4)Tidak melakukan merger; (5)Tidak melakukan IPO dalam kurun periode 2016-2019; (6)Tidak mengalami delisting dari BEI dalam kurun periode 2016-2019. Dari hasil teknik purposive sampling, disimpulkan data riset ini sebanyak 235 observasi.

Tabel 1. Operasionalisasi Variabel

\begin{tabular}{|c|c|}
\hline Variabel & Pengukuran \\
\hline \multicolumn{2}{|l|}{ 1. Variabel Terikat } \\
\hline $\begin{array}{l}\text { Nilai perusahaan (Q) } \\
\text { (Smithers, Andrew \& Wright, 2007) }\end{array}$ & $\mathrm{Q}=(\mathrm{EMV}+\mathrm{D}) /(\mathrm{EBV}+\mathrm{D}) \mathrm{s}$ \\
\hline Variabel & Pengukuran \\
\hline \multicolumn{2}{|l|}{ 2. Variabel Bebas } \\
\hline $\begin{array}{l}\text { Leverage } \\
\text { (Kasmir, 2014) }\end{array}$ & TDA $=\frac{\text { Total Liabilites }}{\text { Total Assets }}$ \\
\hline $\begin{array}{l}\text { Debt Maturity (LTDTD) } \\
\text { (Jamal, Surayya, Naveed \& Malik, 2020); (Orman } \\
\text { \& Köksal, 2017) }\end{array}$ & $\frac{\text { Long term debt }}{\text { Total Debt }}$ \\
\hline \multicolumn{2}{|l|}{ 3.Variabel Kontrol } \\
\hline Firm Size & Ln Assets \\
\hline Likuiditas & $\mathrm{CR}=\frac{\text { Total Current } \text { Assets }}{\text { Total Current Liabilities }}$ \\
\hline Profitabilitas & $\mathrm{ROE}=\frac{\text { Net income }}{\text { Equity }}$ \\
\hline
\end{tabular}

Model penelitian menggunakan analisis regresi data panel dengan persamaan regresi berdasarkan penelitian (Tahir et al., 2020) sebagai berikut:

$\mathbf{Q}_{\mathrm{t}}=\mathbf{a}_{\mathrm{it}}+\mathrm{bTDA}_{\mathrm{it}}+\mathrm{cLTDTD}_{\mathrm{it}}+\mathrm{dSIZE}_{\mathrm{it}}+\mathrm{eCR}_{\mathrm{it}}+\mathrm{fROE}_{\mathrm{it}}+e_{i t}$

Keterangan:

$\mathrm{Q} \quad=$ Firm value

TDA $=$ Total Debt $/$ Total Assets

LTDTD= Long Term Debt / Total Debt

SIZE = Ukuran perusahaan

$\mathrm{CR} \quad=$ Likuiditas

$\mathrm{ROE}=$ Profitabilitas

e $\quad=$ error 


\section{HASIL DAN PEMBAHASAN}

Tabel 2. Statistik Deskrptif

Sumber: output Eviews 10

\begin{tabular}{c|c|c|c|c|c|c}
\hline & TDA & DEBTMAT & SIZE & CR & ROE & TOBINSQ \\
\hline Mean & 0,390848 & 0,274622 & 12,89293 & 2,884973 & 0,153771 & 1,595677 \\
\hline Median & 0,357492 & 0,234859 & 12,37146 & 2,006878 & 0,102424 & 0,764117 \\
\hline Maximum & 3,300808 & 0,789422 & 123,9814 & 45,25028 & 2,244585 & 22,86570 \\
\hline Minimum & 0,076894 & 0,000572 & 10,79815 & 0,025701 & $-0,160567$ & 0,001833 \\
\hline Std. Dev. & 0,256850 & 0.187754 & 7,117884 & 3,555016 & 0,253081 & 2,626355 \\
\hline Skewness & 5,929581 & 0,755900 & 15,42028 & 7,748251 & 4,886675 & 4,491757 \\
\hline Kurtosis & 67,44236 & 2,872602 & 241,1739 & 86,01426 & 30,68092 & 28,38661 \\
\hline & & & & & & \\
\hline Jarque-Bera & 44365,72 & 23,78493 & 596005,4 & 73692,27 & 8904,770 & 7493,564 \\
\hline Probability & 0,000000 & 0,000007 & 0,000000 & 0,000000 & 0,000000 & 0,000000 \\
\hline & & & & & & \\
\hline Sum & 96,93024 & 68,10634 & 3197,447 & 715,4733 & 38,13516 & 395,7279 \\
\hline Sum Sq. Dev. & 16,29507 & 8,707121 & 12514,08 & 3121,620 & 15,82034 & $1703 ., 742$ \\
\hline Observations & 248 & 248 & 248 & 248 & 248 & 248 \\
\hline
\end{tabular}

Berdasarkan tabel statistik deskriptif diatas (tabel 2) dihasilkan bahwa nilai perusahaan, yang diukur dengan Tobins $Q$, mempunyai tingkat rata-rata 1,5956. Artinya bahwa nilai perusahaan dikatakan baik apabila perusahaan menggunakan pembiayaan operasionalnya dengan utang. Selain itu hasil pengujian deskriptif menggambarkan ada 24 kurang lebih perusahaan menggunakan pembiayaan perusahaan menggunakan utang, dihitung dengan 0,39084 dikalikan dengan 62 perusahaan sebagai sampel penelitian. Ukuran perusahaan/ size juga turut mendukung penggunaan utang dalam pembiayaan perusahan dimana dibuktikan dari tabel 2 diatas bahwa perusahaan berukuran besar kebanyakan menggunakan utang sebagai sumber pembiayaannya dikarenakan debt tax shield yang diperolehnya. Nilai likuiditas perusahaan manufaktur yang pembiayaan perusahaannya menggunakan utang menghasilkan nilai rata-rata 2,884 , artinya likuiditas perusahaan tersebut rendah dibandingkan perusahaan yang tidak menggunakan utang sebagai pembiayaan perusahaan. Hal tersebut dikarenakan jumlah utang jangka pendek lebih sedikit dibandingkan jumlah utang jangka panjangnya yang tercantum laporan posisi laporan keuangannya. Profitabilitas/ ROE dalam tabel 2 memiliki rata-rata sebesar 0,1537 yang memiliki arti bahwa perusahaan manufaktur yang pembiayaan perusahaan menggunakan utang dengan harapan mendapatkan debt tax shield, menghasilkan profitabilitas yang tinggi.

\section{Teknik Analisis Model Data Panel}

Uji Chow. Tujuannya adalah memahami model fixed effect atau common effect yang paling baik diterapkan dalam penelitian ini.

Ho: Common Effect

Ha: Fixed Effect

Jika probabilitas chi-square menunjukkan hasil $<5 \%$, maka tidak diterima. Kesimpulannya bahwa penelitian memakai fixed effect. Dimana hasil model penelitiannya:

Tabel 3. Hasil tes Rebundant Fixed Effect-Likelihood Ratio

Sumber: Output Eviews 10

\begin{tabular}{l|ll}
\hline \multicolumn{1}{c|}{ Effect Test } & \multicolumn{1}{c}{ Probabilitas } \\
\hline Cross-section F & 0,00000 \\
\hline Cross-section Chi-square & 0.00000 & \\
\hline
\end{tabular}


Kesimpulannya karena nilai probabilitasnya kurang dari 5\% maka disimpulkan bahwa model penelitian lebih tepat menggunakan model fixed effect. Sehingga dilanjutkan dengan Uji Hausman.

Correlated Random Effect-Hausman Test. Tujuannya agar memahami model random effect atau fixed effect yang paling baik digunakan dalam penelitian ini.

Ho: Random Effect

Ha: Fixed Effect

Jika probabilitas chi-square menunjukkan hasil > 5\%, maka penelitian memakai random effect. Hasil dari estimasi menggunakan efek spesifikasi random adalah sebagai berikut:

Tabel 4. Hasil uji Hausman

Sumber: Output Eviews 10

\begin{tabular}{c|l|l}
\hline \multicolumn{1}{c|}{ Test Summary } & Chi-Sq. Statistic & \multicolumn{1}{c}{ Probabilitas } \\
\hline Cross-section random & 129,713771 & 0,00000 \\
\hline
\end{tabular}

Kesimpulannya adalah nilai Cross-section random memiliki Prob $<5 \%$ sehingga disimpulkan bahwa model yang tepat adalah Fixed Effect dibandingkan Random Effect.

Berdasarkan uji spesifikasi yang telah dibuktikan, penelitian memakai estimasi model fixed effect, dengan hasil estimasi berdasarkan regresi data panel:

Tabel 5. Hasil Estimasi Model

Sumber: Output Eviews 10

\begin{tabular}{l|l|l|l}
\hline \multicolumn{1}{c|}{ Variabel } & \multicolumn{1}{|c|}{ Koefisien } & \multicolumn{1}{c}{ t-statistik } & \multicolumn{1}{c}{ Probabilitas } \\
\hline $\mathrm{C}$ & 1,827935 & 4,724129 & 0,0000 \\
\hline TDA & $-0,077514$ & $-0,180063$ & 0,0857 \\
\hline DEBTMAT & $-0,968949$ & $-0,930747$ & 0,6354 \\
\hline SIZE & 0,000866 & 0,011807 & 0,9416 \\
\hline CR & $-0,006721$ & $-0,230938$ & 0,8176 \\
\hline ROE & $-0,444040$ & $-0,712316$ & 0,4772 \\
\hline \multicolumn{4}{l}{} \\
\hline R-squared & 0,862426 & Mean dependent var & 1,595677 \\
\hline Adjusted R-squared & 0,812260 & S.D. dependent var & 2,626355 \\
\hline F-statistic & 17,19170 & Durbin-Watson stat & 1,620482 \\
\hline
\end{tabular}

Berlandaskan hasil tabel 5, kesimpulannya bahwa pembiayaan perusahaan dengan leverage dan debt maturity terbukti mempengaruhi secara positif atas nilai perusahaan dengan nilia probablitas 0,0000 .

\section{Hasil Uji Signifikansi}

Uji F. Nilai F-hitung dari hasil tabel 5, menunjukkan sebesar 17,19170 dan probabilitas $\mathrm{F}$ sebesar 0,0000 . Peneitian ini menggunakan taraf signifikansi $10 \%$, sehingga disimpulkan bahwa maka uji $\mathrm{F}$ terbukti signifikan. Kesimpulannya bahwa pembiayaan perusahaan memakai leverage (utang jangka panjang) dan debt maturity (utang jangka pendek) berdampak positif terhadap nilai perusahaan manufaktur.

Uji t. Hasil analisis uji t yang terdapat pada tabel 5. menunjukkan bahwa: (1) Pengaruh pembiayaan perusahaan menggunakan total utang (proksi pengukuran TDA) menunjukkan menunjukkan hasil positif terhadap nilai perusahaan, dengan nilai probabilitas kurang dari $10 \%$ (taraf signifikansi) yaitu 8,57\%. (2) Pembiayaan perusahaan yang menggunakan utang jatuh 
tempo (debt maturity) tidak memberikan dampak positif akan nilai perusahaan, dengan dipastikannya nilai probabilitas lebih dari tingkat signifikansi 10\%, yaitu 63,54\%. (3) Variabel kontrol yang digunakan terdiri firm size, likuiditas, dan profitabilitas semuanya tidak ada yang terbukti mempengaruhi secara positif nilai perusahaan manufaktur. Untuk ukuran perusahaan dibuktikan dengan nilai probabilitas melebihi tingkat signifikansi $10 \%$ yaitu $94,16 \%$. Variabel kontrol likuiditas menghasilkan nilai probabilitas sebesar $81,76 \%$, dimana lebih besar dari tingkat signifikansi $10 \%$. Dan variabel kontrol profitiabilitas juga dibuktikan dengan nilai probabilitas sebesar 47,72\%, melebihi nilai tingkat signifikansi $10 \%$.

Koefisien Determinasi $\left(\mathbf{R}^{2}\right)$. $\mathrm{R}^{2}$ atau goodness of fit berdasarkan hasil uji statistitk, nilainya sebesar 0,862426. Arti nilai tersebut adalah variabel bebas yang ada dalam model penelitian memberikan kontribusi menjelaskan variabel terikat sebesar 86,24\%. Dan sebesar 13,76\% memiliki arti bahwa ada variabel-variabel lain di luar model riset mampu menjelaskan variabel terikat.

\section{Pembahasan}

Pengujian data riset menggunakan analisis data panel memiliki tujuan agar dapat memahami bagaiamana pembiayaan perusahaan manufaktur dapat berdampak atas nilai perusahaan tersebut. Dibawah ini tertuliskan model penelitian fixed effect menggunakan regresi data panel:

TOBINSQ $=1,82793-0,07751 *$ TDA $-0,45683 *$ DEBTMAT + 0,00086*SIZE $-0,00672 *$ CR $-0,44404 *$ ROE

Berlandaskan persamaan regresi tersebut, nilai koefisien konstanta sebesar 1,82793. Adapun variabel bebas didalam model yang memberikan dampak atas nilai perusahaan diartikan:

$\mathrm{H} 1$ : Leverage berpengaruh positif terhadap nilai perusahaan.

Sedangkan pengukuran leverage dengan total debt to total assets menyajikan hasil uji berdampak positif atas nilai perusahaan, kesimpulannya hipotesis satu tidak ditolak. Hasil uji tersebut mendukung hasil penelitian (Hermuningsih, 2013) yang melakukan penelitiannya di Indonesia, dimana penambahan leverage dapat menyampaikan sinyal positif untuk penanam modal dan menambah nilai perusahaan. Selain itu hasil penelitian juga mendukung penelitian (Irsan \& Jonnardi, 2019) dikarena semakin besarnya utang yang digunakan membiayai perusahaan pertambangan dapat menghasilkan jumlah produksi lebih besar sehingga dapat meningkatkan nilai perusahaan di mata investor.

H2: Debt maturity berpengaruh negatif terhadap nilai perusahaan.

Debt maturity berdasarkan hasil uji regresi dipastikan bahwa tidak memiliki pengaruh atas nilai perusahaan, dengan nilai probabilitas 0,6354, dengan nilai yang lebih besar dari tingkat signifikansi 0,1 . Alasannya proksi pengukuran utang jangka panjang terhadap total utang tidak secara langsung berhubungan dengan nilai perusahaan. Maka dapat dipastikan bahwa, nilai perusahaan tidak bergantung pada lamanya jatuh tempo utang. Hasil penelitian mendukung hasil penilitian (Dewi, Murti Sari \& Mulyani, E., 2020) bahwa debt maturity tidak berpengaruh terhadap kinerja keuangan. Berdasarkan table deskriptif, utang jangka Panjang yang digunakan membiayai perusahaan manufaktur memiliki rata-rata kurang dari 50\% sehingga disimpulkan bahwa perusahaan manufaktur lebih banyak menggunakan utang jangka pendek membiayai perusahaan dengan alasan bahwa utang jangka pendek tidak menimbulkan bunga yang tinggi untuk dibayarkan sehinga cost of debt nya akan lebih rendah dibandingkan dengan utang jangka Panjang. Nilai cost of debt nya yang rendah tidak mempengaruhi cost of capital sehingga tidak 
mempengaruhi nilai perusahaan manufaktur tersebut (Dewi, Murti Sari \& Mulyani, E., 2020) Selain itu, debt maturity yang lebih lama diyakini akan menjadi keuntungan karena melindungi peminjam dari fluktuasi suku bunga (Chaleeda et al., 2019).

Variabel kontrol. Hasil regresi data panel menyimpulkan bahwa firm size tidak berpengaruh terhadap kinerja keuangan perusahaan manufaktur. Artinya calon investor sangat menyadari bahwa ukuran perusahaan tidak dapat dijadikan jaminan atas kinerja keuangan perusahaan besar, karena perusahaan besar belum tentu didukung oleh manajemen yang baik (Isbanah, 2015). Hasil ini sejalan dengan (Talebria, Ghodratallah, Mahdi Salehi, Hashem Valipour, 2010) dan (Tambunan, Jessica T.A \& Bulan, 2018), dan mereka juga menemukan bahwa firm size tidak berpengaruh terhadap kinerja perusahaan. Hasil regresi data panel juga menunjukkan bahwa likuiditas perusahaan tidak berpengaruh positif terhadap nilai perusahaan. Hal ini dikarenakan likuiditas yang tinggi tidak selalu menjamin akan meningkatkan nilai perusahaan (Wulandari, 2019). Fakta membuktikan bahwa variabel kontrol profitabilitas tidak akan berpengaruh positif terhadap nilai perusahaan. Hal ini dikarenakan calon investor tidak akan menilai apakah perusahaan dalam keadaan baik berdasarkan keuntungan yang diperoleh perusahaan pada saat melakukan investasi, melainkan terdapat faktor lain, seperti kegiatan tanggung jawab sosial perusahaan yang dilakukan oleh perusahaan.

\section{KESIMPULAN DAN SARAN}

Pembiayaan perusahaan menggunakan utang sesuai hasil uji regresi data panel tidak berpengaruh terhadap nilai perusahaan. Alasannya sesuai laporan tahunan yang diperoleh peneliti menemukan bahwa perusahaan manufaktur hanya $30 \%$ menggunakan utang sebagai pembiayaan perusahannya dibandingkan dalam bentuk saham. Hal tersebut yang membuat pembiayaan perusahaan dengan utang tidak berpengaruh positif terhadap nilai perusahaan. Berdasarkan hasil uji regresi data panel, penggunaan pembiayaan perusahaan dengan jatuh tempo utang tidak berpengaruh positif terhadap nilai perusahaan. Pasalnya, rata-rata hanya $28 \%$ perusahaan manufaktur yang tercatat di Bursa Efek Indonesia menggunakan utang jatuh tempo untuk pembiayaan modal perusahaan, dan sisanya menggunakan saham atau keuntungan yang belum dibagikan untuk pembiayaan perusahaan.

Hasil regresi data panel menyimpulkan bahwa besar dan kecilnya suatu perusahaan tidak berpengaruh terhadap kinerja keuangan perusahaan manufaktur. Artinya calon investor sangat memahami bahwa ukuran perusahaan tidak bisa digunakan sebagai jaminan bahwa perusahaan yang besar memiliki kinerja keuangan yang bagus karena perusahaan yang besar belum tentu didukung oleh pengelolaan yang bagus (Isbanah, 2015). Hasil ini sejalan dengan (Talebria, Ghodratallah, Mahdi Salehi, Hashem Valipour, 2010) dan (Tambunan, Jessica T.A \& Bulan, 2018) yang juga menemukan bahwa tidak terdapat pengaruh ukuran perusahaan terhadap kinerja perusahaan. Hasil regresi data panel juga menunjukkan likuiditas perusahaan tidak berpengaruh positif terhadap nilai perusahaan. Hal itu dikarenakan tingginya rasio likuiditas tidak selalu menjamin bahwa akan meningkatkan nilai perusahaan (Wulandari, 2019).

\section{Ucapan Terimakasih}

Penelitian ini di danai oleh Lembaga Penelitian dan Pengabdian Masyarakat (LPPM) Universitas Tarumanagara.

\section{REFERENSI}

Asif, A., \& Aziz, B. (2016). Impact of Capital Structure on Firm Value Creation-Evidence from the Cement Sector of Pakistan. International Journal Research in Finance and Marketing, 6(6), 231-245. http://euroasiapub.org/wp-content/uploads/2016/09/19FMJune-3764-1.pdf 
Barclay, M. J., \& Smith, C. W. (1995). The Maturity Structure of Corporate Debt. The Journal of Finance, 50(2), 609-631. https://doi.org/10.1111/j.1540-6261.1995.tb04797.x

Berlin, M. (2006). Debt maturity: What do economists say? What do CFOs say? Business Review, 3-10. https://fraser.stlouisfed.org/title/business-review-federal-reserve-bankphiladelphia-5580/first-quarter-2006-557736/debt-maturity-522388

Brealey, R.A. \& Myers, S. C. (2003). Principles of Corporate Finance (7th ed.). McGraw Hill.

Brigham, E. F. \&, \& Gapenski, L. C. (2006). Intermediate Financial Management. The Dryden Press.

Brigham, E. F. dan J. F. H. (2014). Dasar-dasar Manajemen Keuangan (S. Empat (ed.); 11th ed.).

Chaleeda, Islam, M. A., Tunku Ahmad, T. S., \& Mosa Ghazalat, A. N. (2019). The Effects of Corporate Financing Decisions on Firm Value in Bursa Malaysia. International Journal of Economics and Finance, 11(3), 127-135. https://doi.org/10.5539/ijef.v11n3p127

Cheng, M.-C., \& Tzeng, Z.-C. (2011). The Effect of Leverage on Firm Value and How The Firm Financial Quality Influence on This Effect. World Journal of Management, 3(2), 30-53. https://pdfs.semanticscholar.org/1ad9/48e3e6bb3c74e0128a91f1f3c89b2a12e75b.pdf.

Daud, W. M. N. W., Norwani, N. M., Mansor, A. A., \& Endut, W. A. (2016). Does financing decision influence corporate performance in Malaysia? International Journal of Economics and Financial Issues, 6(3), 1165-1171. https://www.econjournals.com/index.php/ijefi/article/view/2332

Dewi, Murti Sari \& Mulyani, E. (2020). Pengaruh Kepemilikan Asing, Leverage, Cash Holdings, dan Debt Maturity Terhadap Kinerja Keuangan Perusahaan. Jurnal Eksplorasi Akuntansi, 2(3), 2893-2911. http://jea.ppj.unp.ac.id/index.php/jea/issue/view/25

Ehikioya, B. I. (2009). Corporate governance structure and firm performance in developing economies: Evidence from Nigeria. Corporate Governance: The International Journal of Business in Society, 9(3), 231-243. https://doi.org/10.1108/14720700910964307

Fajaria, A. Z. \& I. (2018). The Effect of Profitability, Liquidity, Leverage and Firm Growth of Firm Value with its Dividend Policy as a Moderating Variable. International Journal of Managerial Studies and Research, 6(10), 55-69. https://doi.org/http://dx.doi.org/10.20431/2349-0349.0610005

Fan, J. P. H., Titman, S., \& Twite, G. (2012). An international comparison of capital structure and debt maturity choices. Journal of Financial and Quantitative Analysis, 47(1), 23-56. https://doi.org/10.1017/S0022109011000597

Hermuningsih, S. (2013). Profitability , Growth Opportunity , Capital. Bulletin of Monetary, Economics and Banking, 16(2), 115-135. https://doi.org/10.21098/bemp.v16i2.440

Hery. (2016). Analisis Laporan Keuangan Integrated And Comprehensive Edition. PT. Gramedia.

Irsan, S. F. \& Jonnardi. (2019). Pengaruh Kinerja Keuangan dan Tingkat Kebijakan Utang Terhadap Nilai Perusahaan dengan Gross Domestic Product Sebagai Variabel Moderator pada Perusahaan Pertambangan Yang Terdaftar di BEI Periode 2015-2017. Jurnal Muara Ilmu Ekonomi Dan Bisnis, 3(2), 289-301. https://doi.org/10.24912/jmieb.v3i2.5101

Isbanah, Y. (2015). Pengaruh ESOP, Leverage, and, Ukuran Perusahaan Terhadap Kinerja Keuangan Perusahaan di Bursa Efek Indonesia. Journal of Research in Economics and Management, 15(1), 28-41. https://doi.org/http://dx.doi.org/10.17970/jrem.15.150103.ID

Jamal, Surayya, Naveed \& Malik, B. (2020). Impact of Debt Maturity on Firm Performance Evidence from Pakistan. International Journal of Business and Management Sciences, 1(1), 65-75. https://www.semanticscholar.org/paper/Impact-of-Debt-Maturity-on-FirmPerformance-from-Jamal-Naveed/aa591d0685213a836474e0b14563c19b6fdd9227?p2df

Jiraporn, P. \&, \& Liu, Y. (2008). Capital structure, staggered boards, and firm value. Financial 
Analysts Journal, 64(1), 49-60. https://doi.org/10.2469/faj.v64.n1.7

Kasmir. (2014). Analisis Laporan Keuangan. Rajawali Pers.

Mohd Tahir, I., \& Razali, A. R. (2011). THE RELATIONSHIP BETWEEN ENTERPRISE RISK MANAGEMENT (ERM) AND FIRM VALUE: EVIDENCE FROM MALAYSIAN PUBLIC LISTED COMPANIES. International Journal of Economics and Management Sciences.

Myers, S. C. (1977). Determinants of corporate borrowing. Journal of Financial Economics, 5(2), 147-175. https://doi.org/10.1016/0304-405X(77)90015-0

Nimalathasan, Balasundaram \& Brabete, V. (2010). Capital Structure and Its Impact on Profitability A Study of Listed Manufacturing Companies in SriLanka. Revista Tinerilor Economisti (The Young Economists Journal), 1(15), 7-16. https://econpapers.repec.org/RePEc:aio:rteyej:v:1:y:2010:i:10:p:7-16

Novari, P., \& Lestari, P. (2016). Pengaruh Ukuran Perusahaan, Leverage, dan Profitabilitas Terhadap Nilai Perusahan pada Sektor Properti dan Real Estate. E-Jurnal Manajemen Universitas Udayana, 5(9). https://ojs.unud.ac.id/index.php/Manajemen/article/view/22690

Octaviana, Lisa Tyas, Hasnawati, Sri, \& Hendrawaty, E. (2019). The Analysis Effect of Leverage, Asymmetric Information and Corporate Governance to Firm Value in Manufacture Companies Listed in Indonesia Stock Exchange. International Journal of Economics, Business and Entrepreneurship, 2(1), 89-96. https://new.feb.unila.ac.id/journal/index.php/ijebe/article/view/49

Orman, C. \&, \& Köksal, B. (2017). Debt maturity across firm types: Evidence from a major developing economy. Emerging Markets Review, 30, 169-199. https://doi.org/10.1016/j.ememar.2016.12.001

Ozkan, A. (2000). An empirical analysis of corporate debt maturity structure. European Financial Management, 6(2), 197-212. https://doi.org/10.1111/1468-036X.00120

Rashid, M., Nor, F. M., \& Ibrahim, I. (2013). Evidence of dividend catering theory in Malaysia: Implications for investor sentiment. Contemporary Economics, 7(4), 99-110. https://doi.org/10.5709/ce.1897-9254.125

Sisca, S. (2018). Pengaruh Leverage dan Profitabilitas Terhadap Nilai Perusahaan dengan Kebijakan Dividen Sebagai Variabel Moderating Pada Perusahaan Manufaktur yang terdaftar di BEI tahun 2010 - 2014. SULTANIST: Jurnal Manajemen Dan Keuangan, 4(1), 1-9. https://doi.org/10.37403/sultanist.v4i1.58

Smithers, Andrew \& Wright, S. (2007). Valuing Wall Stree. McGraw-Hill Companies.

Suaidah, Riski \& Sebrina, N. (2020). Pengaruh Kualitas Pelaporan Keuangan dan Tingkat Jatuh Tempo Utang Terhadap Efisiensi Investasi. Jurnal Eksplorasi Akuntansi, 2(2), 2693-2710. http://jea.ppj.unp.ac.id/index.php/jea/issue/view/23

Sutama, D. R., \& \& Lisa, E. (2018). Pengaruh Leverage dan Profitabilitas Terhadap Nilai Perusahaan. Sains Manajemen Dan Akuntansi, 10(1), 21-39. http://jsma.stan-im.ac.id/wpcontent/uploads/2018/07/03-Dedi-R.pdf

Tahir, H., Masri, R., \& Rahman, M. (2020). Determinants of dividend pay-out policy of listed non-financial firms in Malaysia. International Journal of Financial Research, 11(2), 6876. https://doi.org/10.5430/ijfr.v11n2p68

Talebria, Ghodratallah, Mahdi Salehi, Hashem Valipour, dan S. S. (2010). Empirical Study of the Relationship between Ownership Structure and Firm Performance: Some Evidence of Listed Companies in Tehran Stock Exchange. Journal of Sustainable Development, 3(2), 264-270. https://doi.org/http://dx.doi.org/10.5539/jsd.v3n2p264 
Tambunan, Jessica T.A \& Bulan, P. (2018). Pengaruh Ukuran Perusahaan, Leverage, dan Struktur Modal Terhadap Kinerja Keuangan Perusahaan (Studi pada Perusahaan Manufaktur Sektor Aneka Industri Tahun 2012-2016). Jurnal Ilmu Administrasi Bisni, 7(2), 130-140. https://ejournal3.undip.ac.id/index.php/jiab/article/view/20329.

Tan, S. L. \&, \& Hamid, N. I. N. A. (2016). Capital structure and performance of Malaysia plantation sector. Journal of Advanced Research in Social and Behavioural Sciences, 3(1), 34-45.

Twairesh, A. E. M. (2014). The Impact of Capital Structure on Firm's Performance Evidence from Saudi Arabia. Journal of Applied Finance \& Banking, 4(2), 183-193. https://ideas.repec.org/a/spt/apfiba/v4y2014i2f4_2_12.html

Vo, X. V. \&, \& Ellis, C. (2017). An empirical investigation of capital structure and firm value in Vietnam. Finance Research Letters, 22(C), 90-94. https://doi.org/10.1016/j.frl.2016.10.014

Wang, T. (2015). Capital Structure, Debt Tax Shield, and Firm Value: A Propensity Score Matching Approach [Tufts University]. http://hdl.handle.net/10427/012082

Wulandari, L. (2019). Pengaruh Kepemilikan Manajerial, Tingkat Hutang, dan Likuiditas Terhadap Kinerja Perusahaan. Volatilitas, 1(3), 1-12. http://ejournal.umpwr.ac.id/index.php/volatilitas/article/view/6216/5494 